\title{
Towards a Precarity Agenda
}

\section{Marcel Paret, University of Utah, United States, and University of Johannesburg, South Africa}

It is widely acknowledged that the closing decades of the twentieth century, and the early decades of the twenty-first century, have been marked by growing economic insecurity across the globe. But how we understand this process is highly contested. What are the sources of economic insecurity? To what extent do contemporary forms of economic and political organisation mark a break from the past? What analytical tools do we need to make sense of the current moment? Are new concepts needed, or will well-established concepts suffice? What are the implications of growing economic insecurity for questions of agency, solidarity, class struggle and social change? How does economic insecurity relate to various forms of collective organisation such as trade unions, political parties and community-based organisations?

Guy Standing has been one of the most prolific and visible contributors to these debates. Standing was an economist and director of various projects at the International Labour Organisation (ILO) from 1975 to 2006. Since then he has held various academic positions at Monash University (Australia), University of Bath (UK) and University of London. He is perhaps best-known for his analysis of the "precariat", which he develops over the course of three books: Work After Globalization: Building Occupational Citizenship (2009), The Precariat: The New Dangerous Class (2011), and A Precariat Charter: From Denizens to Citizens (2014).

The third instalment is distinct from the previous two in that it develops twenty-nine proposals - a Precariat Charter - for how to improve the conditions of the precariat. The proposals are wide-ranging. They call for:

- redefining work (Article 1) and reforming labour statistics (Article 2), changing recruitment practices (Article 3) and regulating flexible labour (Article 4), regulating payday and student loans (Article 21), and eliminating poverty and precarity traps (Article 17);

- getting rid of assessment tests (Article 18), abolishing "workfare" programmes (Article 20), stopping class-based migration policies (Articles 11-15) and attacks on the disabled (Article 19), eliminating subsidies and tax breaks for corporations and special interests (Article 24), and re-marginalising charities (Article 29);

- ensuring due process (Article 16) and the right to financial knowledge (Article 22), decommodifying education (Article 23), sharing capital (Article 26) and providing a basic income (Article 25), promoting associational freedom (Article 5) and occupational communities (Articles 6-10), and reviving the commons (Article 27) and deliberative democracy (Article 28).

Standing's Precariat Charter envisions a comprehensive overhaul of global capitalism, if not necessarily its overthrow. The programme it outlines entails the redistribution of resources, the reorganisation of decision-making processes, and the construction of new policies and institutional 
frameworks.

This Special Issue of the Global Labour Journal derives from a panel held at the eighteenth International Sociological Association (ISA) World Congress of Sociology in Yokohama, Japan, in July 2014. Entitled “The Politics of the Precariat: A Dialogue with Guy Standing”, the panel was devoted to a critical analysis of Standing's A Precariat Charter, and also featured a response from Standing. Following the conference, the three critical commentators - Jennifer Chun, Ruy Braga and Marcel Paret - further developed their comments into full papers. Erik Olin Wright and Ben Scully, who were at the ISA conference but did not participate in the panel, were later invited to contribute essays on the same theme.

The resulting Special Issue includes five peer-reviewed articles that engage with Guy Standing's analysis of the precariat. The contributions offer critical reflections on Standing's work, and also draw from the authors' research to develop original theoretical and empirical analysis. The discussion centres on Standing's third book in the precariat series, A Precariat Charter, but the contributors also make reference to the previous two books. Standing was invited to compose a rejoinder to the critiques, and this rejoinder is included in the Special Issue as well.

My aim in this introduction is to take stock of the debate, outlining the most central points of critique or disagreement, and to assess their implications. The critiques of Standing developed across the five critical articles may be organised into two sets. One set of critiques pertains to identifications of precarity, including sticky issues around how to define the class structure and patterns of global variation - particularly the North/South divide. A second set of critiques revolves around questions of agency and class struggle, including the controversial topic of unions, as well as more general strategies for social change.

I take each set of critiques in turn, highlighting both the key points raised by Chun, Braga, Scully, Wright and Paret, and the responses to them by Standing. Building on this synthesis, the second part of the essay proposes a research agenda for future studies of precarity. This proposed agenda focuses on four key areas: classification, space and time, commodification, and struggle.

\section{Identifying Precarity}

Standing's analysis is situated within a broader analysis of the contemporary class structure, which includes seven main groups: "an elite, a salariat, proficians, an old 'core' working class (proletariat), a precariat, the unemployed and a lumpen-precariat (or 'underclass')" (Standing, 2014a: 13). In The Precariat, he defines the precariat as consisting of those who lack seven different forms of security labour market security, employment security, job security, work security, skill reproduction security, income security and representation security - which he suggests defined the "industrial citizenship agenda" of trade unions and social democratic parties in the period immediately following the Second World War (Standing, 2011: 10-11). In A Precariat Charter, he argues that the precariat is defined by distinctive relations of production, relations of distribution and relations to the state, which in turn shape access to various civil, political, cultural, social and economic rights (Standing, 2014a: 16-21).

In his rejoinder, Standing clarifies that this understanding of the class structure is rooted in a process of class fragmentation, which split the working class into four groups: the salariat, proficians, proletariat and precariat. Standing (2014a: 28-31) also differentiates between three "varieties" of the precariat: those who have been expelled from traditional working-class 
communities; traditional "denizens" such as migrants and ethnic minorities; and educated youth. Crucially, in his books Standing suggests that this process of class fragmentation is spreading throughout the globe.

The critics underscore two key problems with Standing's framework. First, they argue that it is inappropriate to consider the precariat as a class, and particularly one that is distinct from some "old" or "core" working class defined by stable employment, and often by access to union membership and work-related benefits. Braga identifies the precariat as including the most "poorly paid and exploited" workers, and suggests that they may usefully be related to what Marx referred to as the "relative surplus population" (151). Paret similarly gropes for a broad interpretation of the proletariat or working class, grounded in experiences of dispossession and dependence on the market, which may include an array of groups with various employment situations.

Wright develops the most thorough and systematic critique of Standing's analytical framework, paying particular attention to the distinction between the precariat and the "old" or "core" working class of stable workers. Drawing on a game-theoretical framework, Wright argues that the precariat and the stable workers are part of the same class because they share the same "objective" "material interest" in replacing capitalism with some "democratic socialist alternative" (132). While admitting that the notion of the precariat may be useful for mobilising around a political programme, at a theoretical level he concludes that "treating the precariat as a class - even as a class-in-the-making - obscures more than it clarifies" (135).

Wright nonetheless concedes that certain reforms within capitalism may potentially help the stable workers and harm the precariat. He therefore suggests that the precariat may be considered a "distinct segment" (133, original emphasis) of the working class. Wright also proposes that the stable workers occupy a "privileged contradictory class location" - a location that is "simultaneously in more than one primary class" - given that their job stability mirrors the capitalist "right to fire an employee" (134).

Standing rejects Wright's approach. He suggests that the analysis is "too abstract", that the "all-embracing working class is a mirage", that the notion of "material interests" is vague and never clearly defined, and that the notion of "contradictory class locations" is used to obscure class differentiation $(191,192)$. He also defends the class distinction between the precariat and the stable workers, pointing to instances where they would support different policies. Further, whereas Wright focuses exclusively on "objective" interests, Standing also incorporates a "subjective" element, noting that "many in the precariat do not believe many in the proletariat or salariat are "there with them" (192, emphasis added).

It is perhaps worth noting that this debate is partially constructed on the terrain of Marxism. Both Wright and Braga, for example, explicitly root their critiques within a Marxist tradition of class analysis. They suggest that, from a Marxist perspective, Standing's class analysis is flawed. But Standing contends that Wrights' theoretical approach, which is organised around the games being played within capitalism and the rules that define them, "seems fundamentally non-Marxist" (191). Positing that Wright has "no focus on relations or forces of production, or incorporation of dialectics", Standing also raises the question of whether his "claim to be Marxist is justified" (191). Conversely, Standing argues that his own conceptualisations of relations of production, relations of distribution and relations to the state are "all Marxian concepts" (192-193).

${ }^{1}$ When page numbers are presented thus, they refer to the page within this Special Issue. 
The stakes of this struggle over the meaning of Marxism are not clearly spelled out by any of the authors. But they relate to issues of agency, class struggle and transformation - topics of longstanding interest within the Marxist tradition - which I address in greater detail below. Specifically, if the precariat and stable workers are distinct classes with opposing interests, building solidarity between them may be perceived as all the more difficult, and possibly even detrimental.

A second critique related to identifying precarity is that Standing's portrayal of global precariat expansion misses important variation, particularly between the Global North and the Global South. This issue has been taken up previously by Munck (2013) and Breman (2013), with their critiques inspiring two responses from Standing (2014b, 2014c). In this special issue, the critique is extended by Scully, Braga and Paret.

Braga and Scully argue that Standing's analysis does not appreciate the extent to which precarity has been a long-standing feature of labour in the South. The different trajectory of labour in the South is asserted most forcefully by Scully, who associates Standing's analysis with a "Eurocentric historical narrative" and a "simplistic assumption of global convergence" (161). He contends that current features of the precariat, such as a "detachment from labour" and lack of citizenship rights, have been present in the South for quite a long time - well before the late twentieth-century shift that Standing associates with the rise of the precariat. Drawing on survey data, Paret shows how experiences of precarity differ dramatically between California in the United States and Gauteng in South Africa, with periods of unemployment much more common in the latter (176). Both Paret and Scully suggest the need for greater attention to the particularities of contemporary precarity in the South.

Standing rejects these critiques on three bases. First, he rejects the claim that he is somehow romantic about the "golden age" of mid-twentieth-century capitalism, and indeed, he is optimistic that the rise of the precariat may signal a shift towards a new order. Second, he asserts that the concept of the precariat was developed through the lens of the South, where much of his early research was based. Third, he rejects the idea that we may speak about a Southern experience of precarity, as Scully in particular aims to do, concluding that "there is no single 'South' model" (199).

Similar to the debate over whether the precariat is a distinct class, the debate over the significance of the North/South divide is deeply entangled with questions of agency and class struggle. Not only does it have implications for historical experiences of class struggle, but it may matter for the types of strategies that are needed to counter growing precarity.

\section{The Precariat and Class Struggle}

Standing's analysis of the precariat is plainly oriented towards possibilities for social change. This is especially clear in A Precariat Charter, which lays out a programme for improving the conditions of the precariat. At least some of the critics are appreciative of this approach. Commending Standing for providing a "model of politically engaged research", Scully applauds his "intellectual courage to advance clear positions about potential solutions to the crisis facing many of the worlds' workers" (160). Similarly, Chun notes how "Standing emphasises that it is time to focus on solutions". She also appreciates what she perceives as a "marked shift in tone and outlook" between The Precariat and A Precariat Charter, published three years apart, towards a position that is "passionately and resolutely optimistic" (137).

Despite these praises, however, the critics nonetheless raise important challenges to Standing's 
vision of social change. They point to three problems. First, they argue that Standing undermines the progressive potential of unions in the contemporary period, especially in the South. Standing's critical stance towards unions is one of the more controversial aspects of his analysis of the precariat. In both The Precariat and A Precariat Charter, he suggests that unions are ill-equipped to respond to growing precarity and, further, that they are largely unattractive to the growing ranks of the precariat. The time for new organisational vehicles, he suggests, is now. Indeed, as Standing clarifies in his rejoinder, Articles 5-10 of his Precariat Charter are devoted precisely "to options for strengthening collective action and representation" for the precariat. Yet some of the critics are not yet prepared to usher unions towards the exit. As Standing accurately notes in his rejoinder, "the commentators are defensive of labour unions" (195).

Braga and Paret are the most defensive of unions. Braga, for example, notes that in Brazil the union Sintratel is reaching out to various marginalised communities, and in turn becoming involved in struggles against the unequal treatment of women, racial discrimination and homophobia. Likewise, Paret cites the example of the National Union of Metalworkers of South Africa (NUMSA), whose United Front project explicitly aims to build solidarity between workplace and community struggles. If Braga and Paret take Standing to task for being too dismissive of unions, Chun launches her critique from the opposite angle. She suggests that Standing is too nostalgic for the fading era of union-driven solidarity, which was always wracked by exclusions of women and workers of colour (137-138, 141). At the same time, however, she suggests that unions have the potential to reconstruct themselves and succeed at "organising the unorganised" (140).

Standing agrees with Chun's central position, affirming the exclusionary logics of unions, but he is perhaps less optimistic about their potential for transformation. Focusing on the Brazilian and Portuguese cases, he suggests that unions remain stale and detached from the precariat. At a more theoretical level, he argues that unions have consistently promoted the decommodification of labour, or work activity (197), while allowing labour-power, the capacity to work, to become ever more precarious. In contrast to this "labourist" agenda, he advocates instead for "the "full commodification of labour', and the decommodification of labour power, people" (199, f.16).

A second criticism related to issues of class struggle is that Standing fails to appreciate alternative organising traditions, particularly by those facing national and racial oppression. Emphasising the importance of identity-based organising traditions in the United States and South Korea, Chun (139-141) criticises Standing for too easily dismissing emerging collectivities of migrant workers. Pointing to the history of migrant-worker organising in California, Paret similarly underscores the potential associated with organising around identities that extend beyond work. In doing so he challenges Standing's proposition that migrants tend to avoid collective struggles, and that educated youth will necessarily lead precariat struggles (185).

Scully's critique of Standing from a Southern perspective mirrors Chun's critique in important ways. Just as Chun finds hope in the legacy of identity-based movements against racial and other forms of exclusion, primarily in the affluent countries of the North, so Scully finds hope in the legacy of "social movement unionism" in the South, which combined bread-and-butter struggles around wages with broader struggles for democratisation. Due to both the longer history of precarity and the legacy of vibrant resistance to it, Scully suggests that anti-precarity politics may be most likely to emerge from the South. It is worth noting that South Africa and Brazil, the two instances of progressive unionism mentioned by Paret and Braga, as well as the case of South Korea noted by Chun, were among the leaders of social movement unionism in the last quarter of the 
twentieth century (Seidman, 1994). The NUMSA-initiated United Front project, highlighted by Paret, explicitly aims to resurrect this legacy.

A third set of criticisms pertaining to class struggle is that Standing's approach is not rooted deeply enough in grassroots organising. Chun critiques what she perceives in Standing to be a false Polanyian optimism - a trend that Burawoy (2010) suggests is endemic within labour studies which suggests that movements against precarity will emerge from the ruins of neo-liberal destruction. While noting that anger and disillusionment are poor bases for collective organising, she also contends that Standing's charter of progressive policies may easily succumb to the "exclusionary logic of liberal democracy", failing to reach the many Others who are often left out of such efforts. Chun's proposed resolution is grassroots organising that emphasises process and building leadership skills among movement participants.

In a kindred critique, Paret notes a tension in A Precariat Charter between, on the one hand, a view of the precariat as a "transformative agent" and, on the other hand, a view of the precariat as "a disorganised force that must be saved from above" (178). While emphasising the need to take the former seriously, Paret detects in Standing's analysis a tendency towards the latter. He also suggests that examining concrete struggles on the ground reveals important moments of solidarity within the precariat. Whereas Standing laments that the precariat is "dangerous", partly because "it is still at war with itself", Paret aims to illustrate that this is not always the case.

Standing does not spend much time in his rejoinder addressing these critiques around organising strategy and internal precariat divisions. In responding to Wright, though, he does clarify that the precariat may find unity "sooner than some observers imagine" (194). He is also unimpressed with mass protest, suggesting that recent examples in Brazil and Portugal did not advance a coherent vision for social change (196). In contrast, he emphasises the need for "collective bodies" that will institutionalise representation for the precariat. While this vision may, possibly, be reconciled with Chun's emphasis on grassroots organising, it is quite different from Paret's excitement about emerging forms of protest.

\section{Towards a Precarity Agenda}

Despite their substantial critiques, all of the authors find some value in Standing's analysis of the precariat. Some appreciate the emphasis on precarity as a feature of the current global political economy. Some appreciate Standing's political engagement and courage in presenting a platform for change, even if others remain sceptical about such a project. Even Wright, who is perhaps the least forgiving, concedes that the notion of the precariat may in fact be useful for characterising a segment of the working class, or for mobilising around a progressive political agenda.

These reflections suggest that pursuing a precariat-inspired research agenda may be valuable. By way of conclusion, in the remainder of the discussion I offer some suggestions for where the study of precarity may go in the future. These proposals take the above critiques as an invitation for exploration, rather than closure. Indeed, this Special Issue is rooted in the hope that a critical engagement with Standing - one of the most visible scholars who has been consistently engaged with issues of labour and precarity - will open up new pathways for both dialogue and study.

Towards this end, I propose that labour scholars may usefully pursue four areas of study, pertaining to classification, space and time, commodification and struggle. These are, of course, not meant to delineate the only useful areas of study for research on precarity. Surely there are many 
more. But each has the potential to significantly improve our understanding of contemporary global capitalism and possibilities for social change. I take each in turn.

\section{Classification}

Standing has probably come under the most fire for his claim that the precariat is a class or a classin-the-making. In this issue, Wright and Braga insist that the precariat should not be distinguished from the working class, or even its more stable and well-off layers. Paret suggests that Standing places too much emphasis on division, as opposed to solidarity, whether that solidarity is actual or aspirational. But Standing's propositions about the current class structure have nonetheless generated useful debate, as the critiques here attest. If one takes Standing's call for a new "vocabulary to meet twenty-first century realities" (199) seriously, further attempts to reconstruct, refine and improve his typologies should be welcomed.

There is, of course, a long history of developing class typologies - rooted in various Marxist, Weberian and Durkheimian traditions - within the field of social stratification. Wright's critique is rooted in a history of stratification research, and his efforts to develop Marxist class analysis in particular. It may be well to consider how Standing's analysis relates to this larger body of scholarship, including other theoretical traditions. In doing so, it will be useful to consider both his reformulated class structure and his analysis of the different varieties of the precariat. To what extent are Standing's typologies defensible? May they be reconstructed to have a firmer theoretical basis? This line of inquiry is important for mapping the current landscape of economic insecurity. Might the metric of economic insecurity be a useful basis for a typology of social locations?

The debate between Wright and Standing also underscores the distinction between "objective" and "subjective" class locations. While Wright emphasises "objective" class distinctions, Standing's typologies, especially his analysis of the varieties of the precariat, incorporate a subjective element. Part of what distinguishes the precariat, for Standing, relates to their very different experiences of the economy and their very different aspirations for the future. This is sticky terrain, not least because objective and subjective measures of class may lead to very different outcomes (Sosnaud, Brady and Frenk, 2013). There is also debate at a theoretical level. Sociological approaches to class analysis tend to downplay subjective identities, even if they do not reject them entirely (Wright, 2005: 182). Alternative approaches, however, emphasise the prominent role of politics, ideology and collective struggle in constituting class divisions (Przeworski, 1985: 60-97).

While certainly not resolving the objective/subjective dilemma - doing so may be impossible - scholars may find it useful to return to Katznelson's (1986) classic study of class formation, which highlights the "process of connection" between four levels: structure, lived experience, value dispositions and collective action. The point is that class may be measured at any of these levels. As scholars seek to develop new typologies or apply well-established ones, they should consider which level of class they are delineating. ${ }^{2}$

\section{Space and time}

Standing's analysis of the precariat has invited debate about the extent of differences between the Global North and the Global South. Whereas critics, both in this Special Issue and elsewhere, have pointed to the distinctiveness of the South, Standing has stood firm to his claims of global

${ }^{2}$ For an analysis of "precarious class formation”, see Paret (2016). 
convergence around a growing precariat. He also questions the relevance of referring to the South, or the existence of a "Southern working class". This debate begs for further empirical investigation, and especially comparative study. To what extent is the class structure similar or different across countries? Does it make sense to use the same categories in different places? If not, what distinguishes the different typologies and how many do we need - two for North and South, or three for low, middle and high income, or five, ten, twenty for even finer distinctions? Conversely, if it is possible to identify comparable categories, then how does the distribution of the population or workforce into these categories vary across contexts?

Answering these questions will necessarily be limited by data availability. Scholars inclined to quantitative approaches should do their best to marshal as much survey data as possible, paying close attention to varying definitions and how questions are worded across contexts. We also need ethnographic approaches that aim to develop classifications based upon prolonged and detailed studies of economic experiences. Comparative studies along these lines will surely be taxing, but they are crucial. Regardless of the approach, quantitative or qualitative, scholars should be careful to also consider the distinction, and articulation, between individuals and households, as highlighted by Scully.

In addition to developing comparisons across space, scholars should also consider developing systematic historical comparisons. Debates around classification are connected to questions of change over time, just as they are linked to variation between places. Specifically, another common critique of Standing is that precarity is far from being a product of a post-1970s economic reorganisation, but rather is a consistent feature of capitalism over time. Neilson and Rossiter (2008: 54), for example, argue that "if we look at capitalism in a wider historical and geographic scope, it is precarity that is the norm and not Fordist economic organization". Further study is needed to test this claim and, in particular, to examine whether current patterns of precarity mirror those that were prevalent during earlier periods.

To cite just one example from the United States, Milkman's (2006) analysis of labour and immigrant organising in Los Angeles points to the possible implications of such historical analysis. She argues that contemporary dynamics - employer offensives, deregulation, deunionisation, declining wages and benefits, deteriorating working conditions - mirror conditions that were prevalent at the beginning of the twentieth century. This cyclical feature, she suggests, is important for union organising efforts. In contrast to the Congress of Industrial Organizations (CIO) unions, which emerged in the context of mass production and consumption in the 1930s, the American Federation of Labor (AFL) unions were forged much earlier. As a result, Milkman argues, AFL unions may be best equipped to organise precarious migrant workers in the present day.

Questions of historical variation are closely entangled with questions of variation across space. Scully, for example, argues that Standing's precariat resembles the working class in the South during the early twentieth century. This claim points towards the need for a broader-reaching historical comparative analysis in the vein of world systems theory. How have certain specific patterns of precarity moved across the globe over time? To what extent would it be appropriate to suggest that the precariat, however defined, has moved from the North in the nineteenth century, to the South in the twentieth century, and then back to the North in the twenty-first century? What is the link between the growth of the precariat in certain locations and longer historical waves of capitalism, such as Kondratieff waves of economic expansion and contraction (Mandel, 1995) or shifting patterns of world hegemony (Arrighi, 1994)? 


\section{Commodification}

These questions of geographic and historical variation are closely tied to a third issue, which unfortunately does not feature prominently in the Special Issue: commodification. Standing argues that mid-twentieth-century Fordism was a "fictitious labour decommodification" because to secure non-wage benefits "one had to be firmly linked to the labour market" (199). This characterisation draws on a vocabulary developed by Polanyi (1944), who argued that land, labour and money are "fictitious commodities" that were not produced for sale on the market. Polanyi argued that subjecting these factors of production to exchange - "disembedding" them from their social foundations - undermined their use value, fuelling the destruction of society.

Standing's portrayal of the rise of the precariat is grounded in a Polanyian analysis of global historical change, where the market is wrenched away from its social foundations through the commodification of everything. He argues in The Precariat.

The globalization era (1975-2008) was a period when the economy was 'disembedded' from society as financiers and neo-liberal economists sought to create a global market economy based on competitiveness and individualism.... A central aspect of globalisation can be summed up in one intimidating word, 'commodification'. This involves treating everything as a commodity, to be bought and sold, subject to market forces, with prices set by demand and supply, without effective 'agency' (a capacity to resist). Commodification has been extended to every aspect of life - the family, education system, firm, labour institutions, social protection policy, unemployment, disability, occupational communities and politics (Standing, 2011: 26).

This portrayal of contemporary global capitalism is similar to Polanyi's analysis of the deepening penetration of "self-regulating" markets in the nineteenth and early twentieth centuries.

Standing is not the only analyst of precarity to invoke Polanyi. Kalleberg (2009: 4), for example, draws on Polanyi's notion of a double movement, where movement towards marketisation inspires counter-movement for social protection. He situates the recent rise of precarious work in the United States within a historical pendulum of flexibility and security, swinging towards market mechanisms and uncertainty up until the 1930s, a social contract and relative certainty from the 1940s to the 1970s, and back to markets and uncertainty in the contemporary period. Breaking the earlier period into two, Burawoy (2015: 25) identifies three waves of marketisation, peaking in the 1830s, 1930s and the present. He also extends the analysis to the global context, suggesting that the three waves are associated, respectively, with colonialism, imperialism and globalisation.

Not unlike Standing, Burawoy's analysis imposes a uniform process of marketisation, glossing over important variation across countries. He hints at such variation when he notes: "Whereas in core countries the waves of marketization have succeeded one another over two centuries, more peripheral countries have had to face these waves in rapid succession, making them all the more explosive" (Burawoy 2015: 24). But this is merely a suggestion, calling for detailed comparative and historical empirical analysis. Such an analysis requires examining precarity in relation to various forms of social protection or, more precisely, their absence.

Standing's notion of "social income" - comprised of the various sources of income one may receive, from money wages to community or state benefits to financial assets - may be a useful analytical tool for carrying forward this analysis of commodification versus social protection. How 
does the composition of social income relate to classifications of precarity? How does it vary across space and time?

A further question is, commodification of what? In his rejoinder, Standing distinguishes between the commodification of labour, the activity, and the commodification of labour-power, or people. He is more concerned with the latter, and even goes so far as to call for the deepening commodification of labour activity. The implication is that the solution to precarity is to focus on decommodifying labour-power. Burawoy makes a similar point when he argues that precarity is best understood as a condition of "ex-commodification", rooted in exclusion from the labour market, rather than an experience of work-based exploitation (Burawoy, 2015: 20-21).

Following this line of inquiry, future scholars may ask, for different groups in different times and places: how does precarity relate to commodification? Is precarity rooted in the commodification of labour, the classic case of exploitation, or is it rooted in the commodification of labour-power, based on exclusion from various sources of social income?

\section{Struggle}

A final important issue for future study on precarity is collective resistance. Consistent with longstanding concerns within labour scholarship, especially those close to Marxist traditions, questions of agency and struggle lie at the heart of debate around Standing's propositions regarding the precariat. Sparked by concerns about how to transition towards a "Good Society", Standing's books on the precariat invite critical thinking about resistance and social change. Even beyond Standing, some scholars embrace the notion of precarity precisely because it may serve as impetus for mobilisation and solidarity (Paret and Gleeson, 2016).

Questions of struggle follow from questions of commodification, especially when situated within a Polanyian framework. Polanyi famously argued that society would spring to protect itself from the ravages and dislocations produced by marketisation. It is this counter-movement that gives rise to the aforementioned pendulum theories of Kalleberg and Burawoy. Some scholars rest their hopes for social change on the emergence of new counter-movements, mirroring those movements of the early twentieth century that gave rise to social protections in the Global North. In Grounding Globalization, for example, Webster, Lambert and Bezuidenhout (2008) place the idea of a countermovement at the centre of a proposed new labour internationalism, which simultaneously extends into local communities and builds cross-national solidarity. While for some this possibility is a pipe dream, the Polanyian counter-movement remains an important analytical tool for theorising both actual and potential collective action. ${ }^{3}$

If Polanyi theorised that marketisation would produce counter-movements for social protection, he was notoriously vague about their class origins. At times he suggests that the working class may lead the charge for social protection, while at other times he suggests that it is society as a whole that will respond. Elsewhere, Michael Levien and I have referred to these as the "agonistic" and "organic" Polanyian hypotheses (Levien and Paret, 2012: 728). The point, however, is that the details of counter-movements are remarkably unclear. If the post-1970s period may be fairly easily associated with marketisation, whether, when and how the other side of the double movement will appear, and who will lead the way, remains an open question.

\footnotetext{
3 See the earlier debate in the Global Labour Journal, including: Burawoy (2010, 2011), Caspersz (2010), Clawson (2010), Evans (2010), Lambert (2010), Webster (2010), Waterman (2011).
} 
The debates in this Special Issue provide a number of points of departure for addressing questions of agency and struggle. Standing's Precariat Charter provides one starting point. To what extent does this political platform resonate with attitudes and concrete struggles on the ground? A second reference point is Chun's grassroots organising tradition, which places greater emphasis on the process of movement-building and internal markers, such as participation and feelings of empowerment, than it does on external targets such as state policy. How prevalent are such efforts, and how effective are they at generating social change? A third area requiring further examination is the politics of unions. Are they simply reproducing "fictitious decommodification", as Standing suggests, or are they moving towards something more transformative, as his critics would have it?

The issue of struggle brings us full-circle, back to the first proposed research agenda around classification. As Paret hints in his critique, class positions may be understood to be determined as much by collective action as they are by objective structural locations or subjective class consciousness. From this perspective, collectivities are forged through concrete struggles, on the ground. But such struggles are far from inevitable, and even when they do exist, they may be reactionary and divisive. To what extent is precarity fuelling fragmentation or solidarity?

The process of collective (class?) formation exploded in the wake of the 2008 global financial crisis, taking centre stage. Even as the Arab Spring, indignados, and Occupy have retreated, collective resistance continues today, often on smaller scales in communities and workplaces. Whether big or small, understanding these struggles - their protagonists and followers, their targets and tactics, their strategies and goals - must be central to the future agenda of research on precarity.

\section{REFERENCES}

Arrighi, Giovanni (1994) The Long Twentieth Century. London: Verso.

Breman, Jan (2013) A Bogus Concept. New Left Review, 84: 130-138.

Burawoy, Michael (2010) From Polanyi to Pollyanna: The False Optimism of Global Labor Studies. Global Labour Journal, 1(2): 301-313.

Burawoy, Michael (2011) On Uncompromising Pessimism: Response to My Critics. Global Labour Journal, 2(1): 73-77.

Burawoy, Michael (2015) Facing an Unequal World. Current Sociology, 63(1): 5-34.

Caspersz, Donella (2010) From Pollyanna to the Pollyanna Principle. Global Labour Journal, 1(3): 393-397.

Clawson, Dan (2010) "False" Optimism: The Key to Historic Breakthroughs? Global Labour Journal, 1(3): 398-400.

Evans, Peter (2010) Is it Labor's Turn to Globalize? Twenty-first Century Opportunities and Strategic Responses. Global Labour Journal, 1(3): 352-379.

Kalleberg, Arne (2009) Precarious Work, Insecure Workers: Employment Relations in Transition. American Sociological Review, 74(1): 1-22.

Katznelson, Ira (1986) Working-class Formation: Constructing Cases and Comparisons. In Workingclass Formation: Nineteenth Century Patterns in Western Europe and the United States, edited by Ira Katznelson and Aristide R. Zolberg. Princeton: Princeton University Press. 
Lambert, Rob (2010) Unionism in One Country is No Longer an Option. Global Labour Journal, 1(3): $388-392$.

Levien, Michael and Marcel Paret (2012) A Second Double Movement? Polanyi and Shifting Global Opinions on Neoliberalism. International Sociology, 27(6): 724-744.

Mandel, Ernest (1995) Long Waves of Capitalist Development. London: Verso.

Milkman, Ruth (2006) L.A. Story: Immigrant Workers and the Future of the U.S. Labor Movement. New York: Russell Sage.

Munck, Ronaldo (2013) The Precariat: A View from the South. Third World Quarterly, 34(5):747-762.

Neilson, Brett and Ned Rossiter (2008) Precarity as a Political Concept, Or, Fordism as Exception. Theory, Culture, \& Society, 25(7-8): 51-72.

Paret, Marcel (2016) Precarious Class Formations in the United States and South Africa. International Labor and Working Class History, 89: 80-106.

Paret, Marcel and Shannon Gleeson (2016) Precarity and Agency through a Migration Lens. Citizenship Studies, 20(3-4): 277-294.

Polanyi, Karl (1944) The Great Transformation: The Political and Economic Origins of Our Time. Boston, MA: Beacon Press.

Przeworski, Adam (1985) Capitalism and Social Democracy. Cambridge: Cambridge University Press.

Seidman, Gay (1994) Manufacturing Militance: Workers Movements in Brazil and South Africa, 1970-1985. Berkeley, CA: University of California Press.

Sosnaud, Benjamin, David Brady and Steven M. Frenk (2013) Class in Name Only: Subjective Class Identity, Objective Class Position, and Vote Choice in American Presidential Elections. Social Problems, 60(1): 81-99.

Standing, Guy (2009) Work after Globalisation: Building Occupational Citizenship. Cheltenham: Elgar.

Standing, Guy (2011) The Precariat: The New Dangerous Class. London: Bloomsbury Academic.

Standing, Guy (2014a) A Precariat Charter: From Denizens to Citizens. London: Bloomsbury Academic.

Standing, Guy (2014b) Understanding the Precariat through Labour and Work. Development and Change, 45(5): 963-980.

Standing, Guy (2014c) Why the Precariat is not a "Bogus Concept". Open Democracy, March 4. Available online at http://www.opendemocracy.net/print/79901 (accessed 28 April 2016).

Waterman, Peter (2011) Beyond Polanyi and Pollyanna - Oscar Wilde? Global Labour Journal, 2(1): 78-83.

Webster, Edward (2010) From Critical Sociology to Combat Sport? Global Labour Journal, 1(3): 384 387.

Webster, Edward, Rob Lambert and Andries Bezuidenhout (2008) Grounding Globalization: Labor in the Age of Insecurity. Oxford: Blackwell.

Wright, Erik Olin (2005) Approaches to Class Analysis. Cambridge: Cambridge University Press. 